\section{SANKSI PIDANA AKIBAT MELAKUKAN PENGULANGAN TINDAK PIDANA NARKOTIKA MENURUT UNDANG-UNDANG NOMOR 35 TAHUN 2009 TENTANG NARKOTIKA ${ }^{1}$}

\author{
Oleh : Meidi M. Lumataw ${ }^{2}$
}

Michael Barama ${ }^{3}$

Mario Mangowal ${ }^{4}$

\begin{abstract}
ABSTRAK
Penelitian ini dilakukan dengan tujuan untuk mengetahui bagaimana sanksi pidana akibat melakukan pengulangan tindak pidana narkotika menurut Undang-Undang Nomor 35 Tahun 2009 Tentang Narkotika dan bagaimana bentuk-bentuk pengulangan tindak pidana menurut Undang-Undang Nomor 35 Tahun 2009 Tentang Narkotika. Dengan menggunakan metode penelitian yuridis normatif, disimpulkan: 1. Sanksi pidana akibat melakukan pengulangan tindak pidana narkotika dalam jangka waktu 3 (tiga) tahun sesuai dengan jenisjenis tindak pidana berdasarkan UndangUndang Nomor 35 Tahun 2009 Tentang Narkotika, maka terhadap pelakunya dikenakan pidana maksimumnya ditambah dengan $1 / 3$ (sepertiga). Ancaman dengan tambahan $1 / 3$ (sepertiga) tidak berlaku bagi pelaku tindak pidana yang dijatuhi dengan pidana mati, pidana penjara seumur hidup, atau pidana penjara 20 (dua puluh) tahun. 2. Bentuk-bentuk pengulangan tindak pidana diatur dalam Pasal 111 sampai dengan Pasal 127 ayat (1), Pasal 128 ayat (1) dan Pasal 129 menurut UndangUndang Nomor 35 Tahun 2009 Tentang Narkotika. Hal ini menunjukkan adanya kepastian hukum dalam peraturan perundangundangan terhadap pihak-pihak yang mengulangi tindak pidana narkotika akan dikenakan pidana maksimumnya ditambah dengan $1 / 3$ (sepertiga).
\end{abstract}

Kata kunci: Sanksi Pidana, Pengulangan Tindak Pidana, Narkotika.

\section{PENDAHULUAN}

\section{A. Latar Belakang}

Meningkatnya jumlah konsumen narkotika semakin memperbesar kemungkinan mereka

\footnotetext{
${ }^{1}$ Artikel Skripsi

2 Mahasiswa pada Fakultas Hukum Unsrat, NIM. 16071101383

${ }^{3}$ Fakultas Hukum Unsrat, Magister IImu Hukum

${ }^{4}$ Fakultas Hukum Unsrat, Magister IImu Hukum
}

terjerat pidana narkotika. Dengan demikian, semakin banyak orang yang harus merasakan dinginnya tembok penjara, kehilangan kesempatan akan pekerjaan dan pendidikan, atau sulitnya mengakses layanan kesehatan karena dipenjara. Diagram berikut menunjukkan kenaikan jumlah tahanan dan narapidana kasus narkotika di Indonesia. ${ }^{5}$

Sebagai kejahatan narkotika yang sudah sejak lama menjadi musuh bangsa, kini narkotika sudah sangat mengkhawatirkan bangsa kita dan seluruh bangsa di dunia saat ini. Produksi dan peredaran narkotika begitu masif beredar di tengah-tengah masyarakat kita. Peran dari para mafia narkotika seakan seperti tdak dapat terbendung lagi. Para mafia narkotika sudah meracuni para penegak hukum sebagai pengguna maupun sebagai pengedar di bangsa Indonesia dan berbagai belahan dunia, walaupun seluruh bangsa memerangi kejahatan ini. Masyarakat sering mendengar pernyataan tentang membangun komitmen atau memerangi bersama dalam memberantas narkotika di negara kita dan seluruh dunia. ${ }^{6}$

Penyakit masyarakat ini sudah menjadi masalah semua negara di dunia, sehingga mayoritas anggota PBB telah menyepakati United Nation Convention Against the Delict Traffic in Narcotics Drugs and Psychotropic Substances pada 1988. Konvensi 1988 yang bertujuan memberantas perdagangan gelap narkotika dan psikotropika. Jika dilihat dari segi isi Konvensi 1988, muncul embrio dari upaya internasional untuk menanggulangi permasalahan organisasi kejahatan transnasional yang antara lain dapat diidentifikasikan dengan aturan-aturan yang menyangkut ekstradisi; bantuan hukum timbal balik; penanganan perdagangan gelap narkoba melalui laut; controlled delivery; penguatan rezim anti pencucian uang (termasuk masalah penyitaan dan perampasan hasil kejahatan narkoba); dan kriminalisasi diversi prekursor dan pengawasan prekursor. ${ }^{7}$

\footnotetext{
${ }^{5}$ Patri Handoyo \& Ingrid Irawati Atmosukarto. 40 Tahun "Perang Melawan Narkotika": Pengelolaan Narkotika oleh Negara, Perang Bukan Solusi.Jurnal Peradilan Indonesia Vol. 5, Agustus 2016-Januari 2017: 9 -26. hlm. 14.

${ }^{6}$ Anton Sudanto. Penerapan Hukum Pidana Narkotika Di Indonesia. ADIL: Jurnal Hukum Vol. 7 No.1. hlm. 139.

${ }^{7}$ lbid. hlm. 140.
} 
Penyalahgunaan narkotika saat ini menjadi perhatian banyak orang dan terus menerus dibicarakan dan dipublikasikan. Ironisnya, tidak hanya dikalangan dewasa saja narkotika begitu dikenal dan dikonsumsi, tetapi dikalangan remaja dan anak dibawah umur pun juga sudah mengenal barang haram tersebut. Fakta yang disaksikan hampir setiap hari baik melalui media cetak maupun elektronik, ternyata peredaran narkotika telah merebak kemanamana tanpa pandang usia. Narkotika merupakan bagian dari narkoba yaitu segolongan obat, bahan atau zat yang jika masuk ke dalam tubuh berpengaruh terutama pada fungsi otak (susunan syaraf pusat) dan sering menimbulkan ketergantungan. Terjadi perubahan dalam kesadaran, pikiran, perasaan, dan perilaku pemakainya. ${ }^{8}$

Pengulangan tindak pidana penyalahgunaan narkotika dapat dilakukan oleh siapapun juga, baik wanita maupun pria, dapat berlangsung pada usia anak, dewasa, maupun lanjut usia. Tindak pidana juga dapat dilakukan secara sadar, setengah sadar, ataupun tidak sadar sama sekali. Seseorang yang melakukan tindak pidana pasti dilatarbelakangi oleh penyebab yang berlainan satu sama lainnya. ${ }^{9}$

\section{B. Rumusan Masalah}

1. Bagaimanakah sanksi pidana akibat melakukan pengulangan tindak pidana narkotika menurut Undang-Undang Nomor 35 Tahun 2009 Tentang Narkotika?

2. Bagaimanakah bentuk-bentuk pengulangan tindak pidana menurut Undang-Undang Nomor 35 Tahun 2009 Tentang Narkotika?

\section{Metode Penelitian}

Metode penelitian yang dipergunakan untuk menyusun penulisan ini ialah metode penelitian hukum normatif, sedangkan data sekunder yang diperoleh dari kepustakaan yang digunakan dalam penulisan ini terdiri dari bahan hukum primer seperti peraturan

\footnotetext{
${ }^{8}$ Hety Ratna Novitasari, Firganefi dan Dona Raisa Monica. Criminological Analysis Towards The Repetition of The Crime of Narcotics Abuse By Child. (Email: hetyratna@ymail.com). Diakses 3/21/2020 8:13 Wita.hlm. 1 (Lihat Ahmadi Sofyan. Narkoba Mengincar Anak Muda. Jakarta. Prestasi Pustaka. 2007. hlm. 12).

${ }^{9}$ lbid. hlm. 3.
}

perundang-undangan mengenai narkotika dan bahan hukum sekunder terdiri dari literaturliteratur, jurnal hukum dan artikel hukum yang membahas materi yang sesuai dengan penulisan ini serta bahan hukum tersier terdiri dari kamus umum dan kamus hukum. Bahan hukum primer dan sekunder dianalisis secara normatif kualitatif.

\section{PEMBAHASAN}

\section{A. Sanksi Pidana Akibat Melakukan Pengulangan Tindak Pidana Narkotika}

Undang-Undang Nomor 35 Tahun 2009

Tentang Narkotika. Pasal 144 ayat:

(1) Setiap orang yang dalam jangka waktu 3 (tiga) tahun melakukan pengulangan tindak pidana sebagaimana dimaksud dalam Pasal 111, Pasal 112, Pasal 113, Pasal 114, Pasal 115, Pasal 116, Pasal 117, Pasal 118, Pasal 119, Pasal 120, Pasal 121, Pasal 122, Pasal 123, Pasal 124, Pasal 125, Pasal 126, Pasal 127 ayat (1), Pasal 128 ayat (1), dan Pasal 129 pidana maksimumnya ditambah dengan $1 / 3$ (sepertiga).

(2) Ancaman dengan tambahan $1 / 3$ (sepertiga) sebagaimana dimaksud pada ayat (1) tidak berlaku bagi pelaku tindak pidana yang dijatuhi dengan pidana mati, pidana penjara seumur hidup, atau pidana penjara 20 (dua puluh) tahun.

Pengulangan tindak pidana (Recidive) yang dilakukan di dalam KUHP adalah jenis Recidive Khusus. Recidive khusus merupakan pengulangan terhadap jenis tindak pidana tertentu dan dalam jangka waktu yang tertentu pula. Selain itu, terdapat pula jenis Recidive umum, yang tidak ditentukan jenis tindak pidana pengulangannya dan tenggang waktunya. Pengaturan mengenai pengulangan tindak pidana pidana dalam KUHP bukan merupakan suatu Aturan Umum, karena tidak terletak pada Buku I KUHP. KUHP memberi pengaturan mengenai pengulangan secara tersebar pada Buku II dan Buku III. Oleh karena itu, muncul istilah Recidive Kejahatan dan Recidive Pelanggaran. ${ }^{10}$

\footnotetext{
10 Rahmi Dwi Sutanti. Kebijakan Aplikatif Pemberatan Pidana Bagi Pelaku Pengulangan Tindak Pidana. Indonesian Journal of Criminal Law Studies II (1) (2017). hIm. 42.
} 
Upaya penanggulangan kejahatan dengan hukum pidana pada hakekatnya juga merupakan bagian dari usaha penegakan hukum (khususnya penegakan hukum pidana). Politik atau kebijakan hukum pidana dapat dikatakan merupakan bagian dari kebijakan penegakan hukum (law enforcement policy). Di samping itu, usaha penanggulangan kejahatan lewat pembuatan undang-undang (hukum) pidana pada hakekatnya juga merupakan bagian integral dari usaha perlindungan masyarakat (social welfare). Kebijakan hukum pidana menjadi sangat wajar bila merupakan bagian integral dari kebijakan atau politik sosial (social policy). ${ }^{11}$

\section{B. Bentuk-Bentuk Pengulangan Tindak Pidana Menurut Undang-Undang Nomor 35 Tahun 2009 Tentang Narkotika}

Peredaran gelap (illegal) narkoba (narkotika dan obat atau bahan berbahaya) memang dipandang sebagai ancaman besar bagi kesehatan warga masyarakat, karena penyalahgunaan (abuse) narkoba ini menimbulkan ketergantungan yang berdampak kepada cara berpikir dan menghilangkan kreativitas seseorang. Ketergantungan ini telah dimanfaatkan untuk bisnis ilegal narkoba oleh sejumlah organisasi kejahatan. ${ }^{12}$

Peredaran narkoba selama ini sangat meresahkan masyarakat kejahatan, korbannya tidak hanya orang dewasa dan remaja bahkan juga anak-anak usia produktif. Upaya Pemerintah dalam memberantas peredaran narkoba dan penyalahgunaan narkotika, yaitu dengan mengeluarkan Undang-Undang Nomor 35 Tahun 2009 tentangNarkotika (selanjutnya ditulis UU Narkotika). Ancaman hukuman dalam UU Narkotika sebagaimana diatur Pasal 132 angka 3 maksimal hukuman mati dan hukuman minimal 1 (satu) tahun. ${ }^{13}$

Berlakunya UU Narkotika seakan tidak membuat efek jera bagi pengedar dan pelaku

\footnotetext{
${ }^{11}$ Anton Sudanto. Op.Cit. hlm. 148.

${ }^{12}$ Mardjono Reksodiputro. Mengantisipasi Pemberantasan Perdagangan llegal Narkotika melalui Sistem Peradilan Pidana (Suatu Observasi untuk Diskusi). Jurnal Peradilan Indonesia Vol. 5, Agustus 2016 - Januari 2017: 53-69. hlm. 54.

${ }^{13}$ Sucipto, Hidayatullah dan Iskandar Wibawa. Peran Balai Pemasyarakatan Dalam Bimbingan Klien Narkoba Guna Mencegah Pengulangan Kejahatan Narkoba. Diakses 3/21/2020 8: 43 Wita. hlm. 21.
}

penyalahgunaan narkotika. Guna menekan angka peredaran narkoba dan menekan jumlah pemakai narkoba, maka narapidana narkoba yang akan menjelang Cuti Bersyarat, Cuti Menjelang Bebas dan Pembebasan Bersyarat, dilakukan pembinaan dan bimbingan oleh Bapas, tujuannya supaya narapidana tersebut tidak mengulangi perbuatannya yang sama di kemudian hari. ${ }^{14}$

Sering sekali penggunaan narkotika bukan untuk kepentingan pengobatan dan ilmu pengetahuan bila dilihat dari keadaan yang demikiandalam tataran empirisnya. Masyarakat sering menggunakan narkotika dengan dosis yang besar sehingga dapat memabukkan dan ketagihan. Oleh sebab itu, kejahatan narkotika dijadikan ajang bisnis yang menjanjikan dan berkembang pesat, yang mana kegiatan ini berimbas pada rusaknya mental baik fisik maupun psikis pemakai narkotika khususnya generasi muda. Penyalahgunaan narkotika sudah di lakukan oleh semua elemen masyarakat. Dari pejabat penegak hukum, pejabat politik, pejabat swasta, mahasiswa, anak-anak. ${ }^{15}$

Pasal 144 Undang-Undang Nomor 35 Tahun 2009 Tentang Narkotika, menyatakan pada ayat (1) Setiap orang yang dalam jangka waktu 3 (tiga) tahun melakukan pengulangan tindak pidana sebagaimana dimaksud dalam Pasal 111, Pasal 112, Pasal 113, Pasal 114, Pasal 115, Pasal 116, Pasal 117, Pasal 118, Pasal 119, Pasal 120, Pasal 121, Pasal 122, Pasal 123, Pasal 124, Pasal 125, Pasal 126, Pasal 127 ayat (1), Pasal 128 ayat (1), dan Pasal 129.

1. Pasal 111 ayat (1) Setiap orang yang tanpa hak atau melawan hukum menanam, memelihara, memiliki, menyimpan, menguasai, atau menyediakan Narkotika Golongan I dalam bentuk tanaman, dipidana dengan pidana penjara paling singkat 4 (empat) tahun dan paling lama 12 (dua belas) tahun dan pidana denda paling sedikit Rp800.000.000,00 (delapan ratus juta rupiah) dan paling banyak Rp8.000.000.000,00 (delapan miliar rupiah). (2) Dalam hal perbuatan menanam, memelihara, memiliki, menyimpan, menguasai, atau

\footnotetext{
${ }^{14}$ Ibid. hlm. 21.

${ }^{15}$ Anton Sudanto. Op.Cit. hlm. 141.
} 
menyediakan Narkotika Golongan I dalam bentuk tanaman sebagaimana dimaksud pada ayat (1) beratnya melebihi 1 (satu) kilogram atau melebihi 5 (lima) batang pohon, pelaku dipidana dengan pidana penjara seumur hidup atau pidana penjara paling singkat 5 (lima) tahun dan paling lama 20 (dua puluh) tahun dan pidana denda maksimum sebagaimana dimaksud pada ayat (1) ditambah $1 / 3$ (sepertiga).

2. Pasal 112 ayat (1) Setiap orang yang tanpa hak atau melawan hukum memiliki, menyimpan, menguasai, atau menyediakan Narkotika Golongan I bukan tanaman, dipidana dengan pidana penjara paling singkat 4 (empat) tahun dan paling lama 12 (dua belas) tahun dan pidana denda paling sedikit Rp. 800.000.000,00 (delapan ratus juta rupiah) dan paling banyak Rp8.000.000.000,00 (delapan miliar rupiah). (2) Dalam hal perbuatan memiliki, menyimpan, menguasai, atau menyediakan Narkotika Golongan I bukan tanaman sebagaimana dimaksud pada ayat (1) beratnya melebihi 5 (lima) gram, pelaku dipidana dengan pidana penjara seumur hidup atau pidana penjara paling singkat 5 (lima) tahun dan paling lama 20 (dua puluh) tahun dan pidana denda maksimum sebagaimana dimaksud pada ayat (1) ditambah $1 / 3$ (sepertiga).

3. Pasal 113 ayat (1) Setiap orang yang tanpa hak atau melawan hukum memproduksi, mengimpor, mengekspor, atau menyalurkan Narkotika Golongan I, dipidana dengan pidana penjara paling singkat 5 (lima) tahun dan paling lama 15 (lima belas) tahun dan pidana denda paling sedikit Rp1.000.000.000,00 (satu miliar rupiah) dan paling banyak Rp10.000.000.000,00 (sepuluh miliar rupiah). (2) Dalam hal perbuatan memproduksi, mengimpor, mengekspor, atau menyalurkan Narkotika Golongan I sebagaimana dimaksud pada ayat (1) dalam bentuk tanaman beratnya melebihi 1 (satu) kilogram atau melebihi 5 (lima) batang pohon atau dalam bentuk bukan tanaman beratnya melebihi 5 (lima) gram, pelaku dipidana dengan pidana mati, pidana penjara seumur hidup, atau pidana penjara paling singkat 5 (lima) tahun dan paling lama 20 (dua puluh) tahun dan pidana denda maksimum sebagaimana dimaksud pada ayat (1) ditambah 1/3 (sepertiga).

4. Pasal 114 ayat (1) Setiap orang yang tanpa hak atau melawan hukum menawarkan untuk dijual, menjual, membeli, menerima menjadi perantara dalam jual beli, menukar, atau menyerahkanNarkotika Golongan I, dipidana dengan pidana penjara seumur hidup atau pidana penjara paling singkat 5 (lima) tahun dan paling lama 20 (dua puluh) tahun dan pidana denda paling sedikit Rp1.000.000.000,00 (satu miliar rupiah) dan paling banyak Rp10.000.000.000,00 (sepuluh miliar rupiah). (2) Dalam hal perbuatan menawarkan untuk dijual, menjual, membeli, menjadi perantara dalam jual beli, menukar, menyerahkan, atau menerima Narkotika Golongan I sebagaimana dimaksud pada ayat (1) yang dalam bentuk tanaman beratnya melebihi 1 (satu) kilogram atau melebihi 5 (lima) batang pohon atau dalam bentuk bukan tanaman beratnya 5 (lima) gram, pelaku dipidana dengan pidana mati, pidana penjara seumur hidup, atau pidana penjara paling singkat 6 (enam) tahun dan paling lama 20 (dua puluh) tahun dan pidana denda maksimum sebagaimana dimaksud pada ayat (1) ditambah 1/3 (sepertiga).

5. Pasal 115 ayat (1) Setiap orang yang tanpa hak atau melawan hukum membawa, mengirim, mengangkut, atau mentransito Narkotika Golongan I, dipidana dengan pidana penjara paling singkat 4 (empat) tahun dan paling lama 12 (dua belas) tahun dan pidana denda paling sedikit Rp800.000.000,00 (delapan ratus juta rupiah) dan paling banyak Rp8.000.000.000,00 (delapan miliar rupiah). (2)Dalam hal perbuatan membawa, mengirim, mengangkut, 
atau mentransito Narkotika Golongan I sebagaimana dimaksud pada ayat (1) dalam bentuk tanaman beratnya melebihi 1 (satu) kilogram atau melebihi 5 (lima) batang pohon beratnya melebihi 5 (lima) gram, pelaku dipidana dengan pidana penjara seumur hidup atau pidana penjara paling singkat 5 (lima) tahun dan paling lama 20 (dua puluh) tahun dan pidana denda maksimum sebagaimana dimaksud pada ayat (1) ditambah $1 / 3$ (sepertiga).

6. Pasal 116 ayat (1) Setiap orang yang tanpa hak atau melawan hukum menggunakan Narkotika Golongan I terhadap orang lain atau memberikan Narkotika Golongan I untuk digunakan orang lain, dipidana dengan pidana penjara paling singkat 5 (lima) tahun dan paling lama 15 (lima belas) tahun dan pidana denda paling sedikit Rp1.000.000.000,00 (satu miliar rupiah) dan paling banyak Rp10.000.000.000,00 (sepuluh miliar rupiah). (2) Dalam hal penggunaan narkotika terhadap orang lain atau pemberian Narkotika Golongan I untuk digunakan orang lain sebagaimana dimaksud pada ayat (1) mengakibatkan orang lain mati atau cacat permanen, pelaku dipidana dengan pidana mati, pidana penjara seumur hidup, atau pidana penjara paling singkat 5 (lima) tahun dan paling lama 20 (dua puluh) tahun dan pidana denda maksimum sebagaimana dimaksud pada ayat (1) ditambah $1 / 3$ (sepertiga).

7. Pasal 117 ayat (1) Setiap orang yang tanpa hak atau melawan hukum memiliki, menyimpan, menguasai, atau menyediakan Narkotika Golongan II, dipidana dengan pidana penjara paling singkat 3 (tiga) tahun dan paling lama 10 (sepuluh) tahun dan pidana denda paling sedikit Rp600.000.000,00 (enam ratus juta rupiah) dan paling banyak Rp5.000.000.000,00 (lima miliar rupiah). (2)Dalam hal perbuatan memiliki, menyimpan, menguasai, menyediakan Narkotika Golongan II sebagaimana dimaksud pada ayat (1) beratnya melebihi 5 (lima) gram, pelaku dipidana dengan pidana penjara paling singkat 5 (lima) tahun dan paling lama 15 (lima belas) tahun dan pidana denda maksimum sebagaimana dimaksud pada ayat (1) ditambah 1/3 (sepertiga).

8. Pasal 118 ayat (1) Setiap orang yang tanpa hak atau melawan hukum memproduksi, mengimpor, mengekspor, atau menyalurkan Narkotika Golongan II, dipidana dengan pidana penjara paling singkat 4 (empat) tahun dan paling lama 12 (dua belas) tahun dan pidana denda paling sedikit Rp800.000.000,00 (delapan ratus juta rupiah) dan paling banyak Rp8.000.000.000,00 (delapan miliar rupiah). (2) Dalam hal perbuatan memproduksi, mengimpor, mengekspor, atau menyalurkan Narkotika Golongan II sebagaimana dimaksud pada ayat (1) beratnya melebihi 5 (lima) gram, pelaku dipidana dengan pidana mati, pidana penjara seumur hidup, atau pidana penjara paling singkat 5 (lima) tahun dan paling lama 20 (dua puluh) tahun dan pidana denda maksimum sebagaimana dimaksud pada ayat (1) ditambah 1/3 (sepertiga).

9. Pasal 119 ayat (1) Setiap orang yang tanpa hak atau melawan hukum menawarkan untuk dijual, menjual, membeli, menerima, menjadi perantara dalam jual beli, menukar, atau menyerahkan Narkotika Golongan II, dipidana dengan pidana penjara paling singkat 4 (empat) tahun dan paling lama 12 (dua belas) tahun dan pidana denda paling sedikit Rp800.000.000,00 (delapan ratus juta rupiah) dan paling banyak Rp8.000.000.000,00 (delapan miliar rupiah).(2) Dalam hal perbuatan menawarkan untuk dijual, menjual, membeli, menerima, menjadi perantara dalam jual beli, menukar, atau menyerahkan Narkotika Golongan II sebagaimana dimaksud pada ayat (1) beratnya melebihi 5(lima) gram, pelaku dipidana dengan pidana mati, pidana penjara seumur hidup, atau pidana penjara paling singkat 5 (lima) tahun 
dan paling lama 20 (dua puluh) tahundan pidana denda maksimumsebagaimana dimaksud pada ayat (1) ditambah $1 / 3$ (sepertiga).

10. Pasal 120 ayat (1) Setiap orang yang tanpa hak atau melawan hukum membawa, mengirim, mengangkut, atau mentransito Narkotika Golongan II, dipidana dengan pidana penjara paling singkat 3 (tiga) tahun dan paling lama 10 (sepuluh) tahun dan pidana denda paling sedikit Rp600.000.000,00 (enam ratus juta rupiah) dan paling banyak Rp5.000.000.000,00 (lima miliar rupiah). (2) Dalam hal perbuatan membawa, mengirim, mengangkut, atau mentransito Narkotika Golongan II sebagaimana dimaksud pada ayat (1) beratnya melebihi 5 (lima) gram maka pelaku dipidana dengan pidana penjara paling singkat 5 (lima) tahun dan paling lama 15 (lima belas) tahun dan pidana denda maksimumsebagaimana dimaksud pada ayat (1) ditambah $1 / 3$ (sepertiga).

11. Pasal 121 ayat (1) Setiap orang yang tanpa hak atau melawan hukum menggunakan Narkotika Golongan II terhadap orang lain atau memberikan Narkotika Golongan II untuk digunakan orang lain, dipidana dengan pidana penjara paling singkat 4 (empat) tahun dan paling lama 12 (dua belas) tahun dan pidana denda paling sedikit Rp800.000.000,00 (delapan ratus juta rupiah) dan paling banyak Rp8.000.000.000,00 (delapan miliar rupiah). (2) Dalam hal penggunaan Narkotika terhadap orang lain atau pemberian Narkotika Golongan II untuk digunakan orang lain sebagaimana dimaksud pada ayat (1) mengakibatkan orang lain mati atau cacat permanen, pelaku dipidana dengan pidana mati, pidana penjara seumur hidup, atau pidana penjara paling singkat 5 (lima) tahun dan paling lama 20 (dua puluh) tahun dan pidana denda maksimum sebagaimana dimaksud pada ayat (1) ditambah $1 / 3$ (sepertiga).

12. Pasal 122 ayat (1) Setiap orang yang tanpa hak atau melawan hukum memiliki, menyimpan, menguasai, atau menyediakan Narkotika Golongan III, dipidana dengan pidana penjara paling singkat 2 (dua) tahun dan paling lama 7 (tujuh) tahun dan pidana denda paling sedikit Rp400.000.000,00 (empat ratus juta rupiah) dan paling banyak Rp3.000.000.000,00 (tiga miliar rupiah). (2)Dalam hal perbuatan memiliki, menyimpan, menguasai, menyediakan Narkotika Golongan III sebagaimana dimaksud pada ayat (1) beratnya melebihi 5 (lima) gram, pelaku dipidana dengan pidana penjara paling singkat 3 (tiga) tahun dan paling lama 10 (sepuluh) tahun dan pidana denda maksimum sebagaimana dimaksud pada ayat (1) ditambah 1/3 (sepertiga).

13. Pasal 123 ayat (1) Setiap orang yang tanpa hak atau melawan hukum memproduksi, mengimpor, mengekspor, atau menyalurkan Narkotika Golongan III, dipidana dengan pidana penjara paling singkat 3 (tiga) tahun dan paling lama 10 (sepuluh) tahun dan pidana denda paling sedikit Rp600.000.000,00 (enam ratus juta rupiah) dan paling banyak Rp5.000.000.000,00 (lima miliar rupiah). (2) Dalam hal perbuatan memproduksi, mengimpor, mengekspor, atau menyalurkan Narkotika Golongan III sebagaimana dimaksud pada ayat (1) beratnya melebihi 5 (lima) gram, pelaku dipidana dengan pidana penjara paling singkat 5 (lima) tahun dan paling lama 15 (lima belas) tahun dan pidana denda maksimumsebagaimana dimaksud pada ayat (1) ditambah $1 / 3$ (sepertiga).

14. Pasal 124 ayat (1) Setiap orang yang tanpa hak atau melawan hukum menawarkan untuk dijual, menjual, membeli, menerima, menjadi perantara dalam jual beli, menukar, atau menyerahkan Narkotika Golongan III, dipidana dengan pidana penjara paling singkat 3 (tiga) tahun dan paling lama 10 (sepuluh) tahun dan pidana denda paling sedikit Rp600.000.000,00 (enam ratus juta rupiah) dan paling banyak Rp5.000.000.000,00 (lima miliar 
rupiah). (2) Dalam hal perbuatan menawarkan untuk dijual, menjual, membeli, menerima, menjadi perantara dalam jual beli, menukar, atau menyerahkan Narkotika Golongan III sebagaimana dimaksud pada ayat (1) beratnya melebihi 5 (lima) gram, pelaku dipidana dengan pidana penjara paling singkat 5 (lima) tahun dan paling lama 15 (lima belas) tahun dan pidana denda maksimumsebagaimana dimaksud pada ayat (1) ditambah 1/3 (sepertiga).

15. Pasal 125 ayat (1) Setiap orang yang tanpa hak atau melawan hukum membawa, mengirim, mengangkut, atau mentransito Narkotika Golongan III, dipidana dengan pidana penjara paling singkat 2 (dua) tahun dan paling lama 7 (tujuh) tahun dan pidana denda paling sedikit $\mathrm{Rp} \quad 400.000 .000,00$ (empat ratus juta rupiah) dan paling banyak Rp3.000.000.000,00 (tiga miliar rupiah). (2)Dalam hal perbuatan membawa, mengirim, mengangkut, atau mentransito Narkotika Golongan III sebagaimanadimaksud pada ayat (1) beratnya melebihi 5 (lima) gram maka pelaku dipidana dengan pidana penjara paling singkat 3 (tiga) tahun dan paling lama 10 (sepuluh) tahun dan pidana denda maksimumsebagaimana dimaksud pada ayat (1) ditambah $1 / 3$ (sepertiga).

16. Pasal 126 ayat (1) Setiap orang yang tanpa hak atau melawan hukum menggunakan Narkotika Golongan III terhadap orang lain atau memberikan Narkotika Golongan III untuk digunakan orang lain, dipidana dengan pidana penjara paling singkat 3 (tiga) tahun dan paling lama 10 (sepuluh) tahun dan pidana denda paling sedikit Rp600.000.000,00 (enam ratus juta rupiah) dan paling banyak Rp5.000.000.000,00 (lima miliar rupiah). (2) Dalam hal penggunaan Narkotika terhadap orang lain atau pemberian Narkotika Golongan III untuk digunakan orang lain sebagaimana dimaksud pada ayat (1) mengakibatkan orang lain mati atau cacat permanen, pelaku dipidana dengan pidana penjara paling singkat 5 (lima) tahun dan paling lama 15 (lima belas) tahun dan pidana denda maksimumsebagaimana dimaksud pada ayat (1) ditambah 1/3 (sepertiga).

17. Pasal 127 ayat (1)Setiap Penyalah Guna: a.Narkotika Golongan I bagi diri sendiri dipidana dengan pidana penjara paling lama 4 (empat) tahun; b.Narkotika Golongan II bagi diri sendiri dipidana dengan pidana penjara paling lama 2 (dua) tahun; dan c. Narkotika Golongan III bagi diri sendiri dipidana dengan pidana penjara paling lama 1 (satu) tahun.

18. Pasal 128 ayat (1) Orang tua atau wali dari pecandu yang belum cukup umur, sebagaimana dimaksud dalam Pasal 55 ayat (1) yang sengaja tidak melapor, dipidana dengan pidana kurungan paling lama 6 (enam) bulan atau pidana denda paling banyak Rp1.000.000,00 (satu juta rupiah).

Penggunaan narkotika oleh anak bukan sekedar permasalahan penegakan hukum. Permasalahan tersebut kompleks dan multiaspek. Oleh karenanya, persoalan pemakaian narkotika seharusnya tidak dipandang sebagai persoalan hukum semata. Ada banyak aspek yang harus dikaji dan dijadikan pertimbangan utama (primary consideration) terutama aspek kesehatan dan aspek sosial para pengguna narkotika dengan berbasis pada bukti. Pada konteks anak pengguna narkotika, maka negara juga harus melihat kepentingan terbaik anak, kerentanan, dan asumsi akan ketidakmatangan berfikir anak sebagai pertimbangan dalam membuat kebijakan narkotika. ${ }^{16}$

Selama ini pemberian hukuman menjadi cara utama untuk membuat jera pelaku kriminal. Pendekatan ini masih dapat digunakan tetapi bukan satu-satunya cara dan bukan juga cara yang paling efektif. Beberapa cara lain

\footnotetext{
${ }^{16}$ Naila Rizqi Zakiah. Menelusuri Perlindungan Hak Anak Pengguna Narkotika dalam Kerangka Hak Asasi Manusia Internasional. Jurnal Peradilan Indonesia Vol. 5, Agustus 2016 - Januari 2017: 27-52. hlm. 28-29.
} 
diusulkan dan diterapkan dalam usaha pencegahan kejahatan, di antaranya: membatasi kesempatan dilakukannya tingkah laku kriminal, memfasilitasi warga untuk dapat menjaga dirinya dari kejahatan, memberikan tanda-tanda peringatan kepada orang-orang yang potensial menjadi korban kejahatan, dan penerapan program pengawasan oleh warga yang menekankan peran aktif masyarakat dalam upaya pencegahan kejahatan. Itu semua baik untuk dilakukan tetapi perlu terintegrasi dalam masyarakat. Untuk menghasilkan program pencegahan kejahatan yang terintegrasi diperlukan strategi yang tepat dan memadai. ${ }^{17}$

Perilaku menyimpang anak-anak (atau yang disebut juga dengan deliquency) tidak dapat dipandang mutlak sama dengan perbuatan menyimpang yang dilakukan orang dewasa. Meskipun pada prinsipnya jenis perbuatannya sama, namun tingkat kematangan fisik dan emosi anak masih rendah, dan masa depan anak seharusnya menjadi pertimbangan dalam hal menentukan perlakuan yang tepat terhadap mereka. ${ }^{18}$

Peradilan pidana (juvenile justice) merupakan salah satu bentuk perlindungan yang diberikan hukum kepada anak yang telah melakukan tindak pidana narkotika. Orientasi dari keseluruhan proses peradilan pidana anak ini harus ditujukan pada kesejahteraan anak, dengan dilandasi prinsip kepentingan terbaik anak (the best interest for children). ${ }^{19}$

Kondisi anak yang sangat mengkhawatirkan saat ini seharusnya menjadi perhatian utama pemerintah dan masyarakat. Realita menunjukkan kesejahteraan anak saat ini masih menghadapi berbagai tantangan. Tidak sedikit anak yang menjadi korban

\footnotetext{
${ }^{17}$ Ibid. hlm. 42-43.

${ }^{18}$ Dery Ulum. Perlindungan Anak dalam Kebijakan Narkotika: Tindak Pidana Narkotika yang Dilakukan Anak. Jurnal Peradilan Indonesia Vol. 5, Agustus 2016 - Januari 2017: 87-10. hlm. 93.

${ }_{19}$ lbid. hlm. 93-94.
}

kejahatan dan eksploitasi, dan tidak sedikit pula anak-anak yang melakukan perbuatan menyimpang, dari sekedar kenakalan hingga mengarah pada bentuk tindakan kriminal, seperti narkoba, minuman keras, perkelahian, pengrusakan, pencurian bahkan pembunuhan. Dalam perkembangannya, banyak anak di Indonesia yang terlibat kasus pidana narkotika, seperti data yang dikemukakan Komisi Perlindungan Anak Indonesia (KPAI) dalam kurun waktu tiga tahun, jumlah pengedar narkoba anak meningkat hingga 300 persen, mulai dari tahun 2012 sebanyak 17 anak, tahun 2013 sebanyak 31 anak, tahun 2014 ada 42 anak. $^{20}$

19. Pasal 129. Dipidana dengan pidana penjara paling singkat 4 (empat) tahun dan paling lama 20 (dua puluh) tahun dan denda paling banyak Rp5.000.000.000,00 (lima miliar rupiah) setiap orang yang tanpa hak atau melawan hukum: a.memiliki, menyimpan, menguasai, atau menyediakan Prekursor Narkotika untuk pembuatan Narkotika; b.memproduksi, mengimpor, mengekspor, atau menyalurkan Prekursor Narkotika untuk pembuatan Narkotika; c.menawarkan untuk dijual, menjual, membeli, menerima, menjadi perantara dalam jual beli, menukar, atau menyerahkan Prekursor Narkotika untuk pembuatan Narkotika; d. membawa, mengirim, mengangkut, atau mentransito Prekursor Narkotika untuk pembuatan Narkotika.

Perkara pidana, strafzaak, yaitu delik yang merupakan objek perkara pidana. ${ }^{21}$ Tindak pidana, yaitu: setiap perbuatan yang diancam hukuman sebagai kejahatan atau pelanggaran

\footnotetext{
${ }^{20}$ lbid. hlm. 93 (LihatAkmal Fauzi, Jumlah Anak di Bawah Umur Jadi Pengedar Narkoba Meningkat, diakses dari http://

news.metrotvnews.com/read/2015/04/27/119920/jumla h-anak-di-bawah-umur-jadipengedar-narkoba-meningkat) diakses pada tanggal 5 November 2016 pukul 10.45 WITA).

${ }^{21}$ Andi Hamzah, Op.Cit. hlm. 118
} 
baik yang disebut dalam KUHPidana maupun peraturan perundang-undangan lainnya. ${ }^{22}$

Bilamana suatu perbuatan dapat disebut sebagai suatu tindak pidana, maka perbuatan tersebut harus memenuhi 5 (lima) unsur, sebagai berikut:

1. Harus ada suatu kelakuan (gedraging);

2. Kelakuan itu harus sesuai dengan uraian undang-undang (wetterlijkeomshrijving);

3. Kelakuan itu adalah kelakuan tanpa hak (melawan hukum);

4. Kelakuan itu dapat diberatkan (dipertanggungjawabkan) kepada pelaku;

5. Kelakuan itu diancam dengan pidana. ${ }^{23}$

Delik kejahatan dan delik pelanggaran dikenal dalam rumusan pasal-pasal KUHP Indonesia yang berlaku sampai sekarang ini, akan tetapi pembentuk undang-undang tidak menjelaskan secara tegas apa yang dimaksud dengan delik kejahatan dan delik pelanggaran, juga tidak ada penjelasan mengenai syaratsyarat yang membedakan antara delik kejahatan dan delik pelanggaran. KUHP hanya mengelompokkan perbuatan-perbuatan yang terdapat dalam Buku II (Kedua) sebagai delik kejahatan dan dan Buku III (Ketiga) sebagai delik pelanggaran. ${ }^{24}$

\section{PENUTUP}

\section{A. Kesimpulan}

1. Sanksi pidana akibat melakukan pengulangan tindak pidana narkotika dalam jangka waktu 3 (tiga) tahun sesuai dengan jenis-jenis tindak pidana berdasarkan Undang-Undang Nomor 35 Tahun 2009 Tentang Narkotika, maka terhadap pelakunya dikenakan pidana maksimumnya ditambah dengan $1 / 3$ (sepertiga). Ancaman dengan tambahan 1/3 (sepertiga) tidak berlaku bagi pelaku tindak pidana yang dijatuhi dengan pidana mati, pidana penjara seumur hidup, atau pidana penjara 20 (dua puluh) tahun.

2. Bentuk-bentuk pengulangan tindak pidana diatur dalam Pasal 111 sampai

\footnotetext{
${ }^{22}$ Rocky Marbun, Deni Bram, Yuliasara Isnaeni dan Nusya A., Op.Cit, hlm. 311

${ }^{23}$ Roni Wiyanto, Asas-Asas Hukum Pidana, Cetakan ke-I. Mandar Maju, Bandung, 2012, hlm. 163-164 (Lihat C.S.T. Kansil, Pengantar IImu Hukum dan Tata Hukum Indonesia, Balai Pustaka, Jakarta, 1989, hlm. 290). ${ }^{24} \mathrm{lbid}$, hlm. 169.
}

dengan Pasal 127 ayat (1), Pasal 128 ayat (1) dan Pasal 129 menurut UndangUndang Nomor 35 Tahun 2009 Tentang Narkotika. Hal ini menunjukkan adanya kepastian hukum dalam peraturan perundang-undangan terhadap pihakpihak yang mengulangi tindak pidana narkotika akan dikenakan pidana maksimumnya ditambah dengan $1 / 3$ (sepertiga).

\section{B. Saran}

1. Sanksi pidana akibat melakukan pengulangan tindak pidana narkotika perlu diterapkan sesuai dengan bentukbentuk tindak pidana yang dilakukan, mengingat pelaku telah melakukan pengulangan tindak pidana. Upaya penegakan hukum akan berjalan efektif apabila hukuman yang dikenakan kepada pelaku tindak pidana benar-benar mampu memberikan efek jera.

2. Bentuk-bentuk pengulangan tindak pidana sebagaimana diatur dalam Undang-Undang Nomor 35 Tahun 2009 Tentang Narkotika memerlukan dukungan pengawasan dan pembinaan yang efektif oleh pihak aparatur hukum khususnya bagi narapidana yang sementara menjalani hukuman agar tidak lagi melakukan pengulangan perbuatan tindak pidana narkotika.

\section{DAFTAR PUSTAKA}

Arief Mansur M. Dikdik \& Elisatris Gultom, Urgensi Perlindungan Korban Kejahatan (Antara Norma dan Realita), PT RajaGrafindo Persada, Jakarta, 2007.

Hadi Sahid. Reformulasi Kebijakan Narkotika: Penegasan Unsur Mens Rea sebagai Jaminan Hak Pecandu Narkotika. Jurnal Peradilan Indonesia Vol. 5, Agustus 2016-Januari 2017: 71-86.

Handoyo Patri \& Ingrid Irawati Atmosukarto. 40 Tahun "Perang Melawan Narkotika": Pengelolaan Narkotika oleh Negara, Perang Bukan Solusi.Jurnal Peradilan Indonesia Vol. 5, Agustus 2016-Januari 2017.

Hamzah Andi, Terminologi Hukum Pidana, (Editor) Tarmizi, Ed. 1. Cet. 1. Sinar Grafika, Jakarta, 2008. 
Marbun Rocky, Deni Bram, Yuliasara Isnaeni dan Nusya A., Kamus Hukum Lengkap (Mencakup Istilah Hukum \& Perundang-Undangan Terbaru, Cetakan Pertama, Visimedia, Jakarta. 2012.

Marpaung Leden, Asas-Teori-Praktik Hukum Pidana, Sinar Grafika. Cetakan Kedua, Jakarta, 2005.

Masriani Tiena Yulies. Pengantar Hukum Indonesia, Cetakan Kelima, Sinar Grafika, Jakarta. 2009.

Meliala Adrianus. Badan Narkotika Nasional dan Jebakan Kelembagaan.Evaluasi Kebijakan Hukum Narkotika Di Indonesia. Jurnal Peradilan Indonesia. Teropong. Vol. 5, Agustus 2016-Januari 2017: 1-8. ISSN 2460-2043.

Moeljatno, Asas-Asas Hukum Pidana, Edisi Revisi, PT. Rineka Cipta, Jakarta, 2008.

Novitasari Ratna Hety, Firganefi dan Dona Raisa Monica. Criminological Analysis Towards The Repetition of The Crime of Narcotics Abuse By Child. (Email: hetyratna@ymail.com)._Diakses 3/21/2020 8:13 Wita.

Paramida Cici. Model Pembinaan Klien Narkoba Dalam Rangka Pencegahan Pengulangan Tindak Pidana Narkotika. Diakses 3/21/2020 8:21 Wita.

Putra Hadi Maksum. Sanksi Pidana Terhadap Anak Yang Melakukan Pengulangan Tindak Pidana (Residive) Criminal Sanctions on Recidivist Children. Jurnal IUS| Vol IV | Nomor 2 | Agustus 2016.

Reksodiputro Mardjono. Mengantisipasi Pemberantasan Perdagangan Ilegal Narkotika melalui Sistem Peradilan Pidana (Suatu Observasi untuk Diskusi). Jurnal Peradilan Indonesia Vol. 5, Agustus 2016 - Januari 2017.

Sudanto Anton. Penerapan Hukum Pidana Narkotika Di Indonesia. ADIL: Jurnal Hukum Vol. 7 No.1.

Sucipto, Hidayatullah dan Iskandar Wibawa. Peran Balai Pemasyarakatan Dalam Bimbingan Klien Narkoba Guna Mencegah Pengulangan Kejahatan Narkoba. Diakses 3/21/2020 8: 43 Wita.

Sunarso Siswantoro, Penegakan Hukum Psikotropika, Dalam Kajian Sosiologi
Hukum, PT. RajaGrafindo Persada, Jakarta, 2004.

Sutanti Dwi Rahmi. Kebijakan Aplikatif Pemberatan Pidana Bagi Pelaku Pengulangan Tindak Pidana. Indonesian Journal of Criminal Law Studies II (1) (2017).

Syamsuddin Aziz, Tindak Pidana Khusus, (Editor) Tarmizi, Ed. 1. Cet.1, Sinar Grafika, Jakarta, 2011.

Ulum Dery. Perlindungan Anak dalam Kebijakan Narkotika: Tindak Pidana Narkotika yang Dilakukan Anak. Jurnal Peradilan Indonesia Vol. 5, Agustus 2016 Januari 2017.

Wiyanto Roni, Asas-Asas Hukum Pidana, Cetakan ke-I. Mandar Maju, Bandung, 2012.

Zakiah Rizqi Naila. Menelusuri Perlindungan Hak Anak Pengguna Narkotika dalam Kerangka Hak Asasi Manusia Internasional. Jurnal Peradilan Indonesia Vol. 5, Agustus 2016 Januari 2017. 